\title{
Normative Institutional Factors Affecting Entrepreneurial Intention in Iranian Information Technology Sector
}

\author{
Zahra Arasti (Corresponding author) \\ Faculty of Entrepreneurship \\ University of Tehran \\ Tehran, Iran
}

Tel: +98-216-111-9227_ E-mail: Arasti@ut.ac.ir

Fatemeh Ahmadi Pasvishe

University of Tehran

Tehran, Iran

Tel: +98-212-236-4636 E-mail: f_ahmadi@ut.ac.ir

Mahmoud Motavaseli

Faculty of Economic

University of Tehran

Tehran, Iran

Tel: +98-216-111-8058＿ E-mail: motavasilm@ut.ac.ir

Received: January 20, 2012

doi: $10.5430 /$ jms.v3n2p16
Accepted: March 14, $2012 \quad$ Published: April 15, 2012

URL: http://dx.doi.org/10.5430/jms.v3n2p16

\begin{abstract}
The entrepreneurial intention has been considered as the key element to understand the new-firm creation process. Environment is an important element in entrepreneurship and entrepreneurial intention is affected by environmental events. In fact, environment could be either a facilitator or an impediment to entrepreneurial intention in a society. Institution is an important factor in entrepreneurship fostering and identifying the target group's needs is the first step in entrepreneurship development with institutional approach. This approach to entrepreneurship result in focusing on norms, believes and regulatory affecting individual and organizations which differ in different societies and cultures.

The Purpose of this study is to identify the effective normative Institutional factors on entrepreneurial intention in Iranian context based on institutional theory and theory of planned behavior. This is a qualitative study using semi-structured interviews on a sample of 10 entrepreneurs in Information Technology (IT) sector. After content analysis, the results will reveal a list of the normative institutional factors which affect entrepreneurs' intention. These factors consist of "family context", "societies' norms and believe"," the expectations from women" and "the technology growth in a country" which play an important role on entrepreneur's intention to start a firm in Information Technology sector in Iran.
\end{abstract}

Keywords: Institutional theory, Normative, Entrepreneurial Intention, Information Technology Sector

\section{Introduction}

Previous studies have revealed the importance and influences of a country's institutional profile on entrepreneurship (e.g., Ahlstrom and Bruton, 2006; Manolova et al., 2008). Institutional theory explains how organizational behavior is shaped by its surrounding institutional forces. The institutional factors based on Scott framework can be classified into three types: regulatory, cognitive and normative. Regulatory institutions represent the codified sets of laws and regulations and government policies formally designed to enforce the structure aimed to support entrepreneurial endeavors. Cognitive institutional dimension refers to people's underlying beliefs, knowledge and skills necessary for enchanting entrepreneurial initiatives. Normative institutional dimension includes the prevailing sets of standards and values by which 
entrepreneurial behavior is accepted in the country (Scott, 2007). These three institutional dimensions have claimed to exert powerful influence to shape the entrepreneurial activity of a country (Ahlstrom and Bruton, 2006; Manolova, et al., 2008).

Humans are active agents in their own development. They do not engage in entrepreneurship by accident; they do it intentionally as a result of choice (Krueger, 2007). Theory of planned behavior argues that intentions in general depend on perceptions of personal attractiveness, social norms, and feasibility. As intentions have been shown to be a good predictor of subsequent behavior (e.g. Ajzen, 2001), understanding the identity and nature of the antecedent factors that influence entrepreneurial intentions is of crucial importance to the study of entrepreneurial behavior (Shane and Venkataraman, 2000).

Environment is an important element in entrepreneurship and entrepreneurial intention are affected by environmental events. In fact environment could be a facilitator or impediment to entrepreneurial intention in a society (Korunka et al., 2003). Institution is an important factor in entrepreneurship fostering and identifying the target group' needs is the first step in entrepreneurship development with institutional approach. The impact of institutions on new firm entry has received a great deal of study. This approach to entrepreneurship result in focusing on norms, believes and regulatory affecting individual and organizations which differ in different societies and cultures. In order to promote entrepreneurship in Iran, study the entrepreneurial intention and the influence of environment on it is crucial.

In this study, we use the concept of social norms, defined as unwritten rules of conduct of a group (Elster, 1989), as a way to study how private, decentralized institutions (Ingram and Silverman, 2002) impact the creation of environmentally responsible new ventures. Thus, the main question of this research is that" what are the normative institutional factors affecting entrepreneurial intention in Information technology sector in Iran?"

This paper is organized as follows: the next section contains a review of the literature on entrepreneurial Intention, institutional theory and its influence on entrepreneur's intention to new venture creation. This discussion leads up to the normative context of entrepreneurs. Section 3 consists of a description of the methods employed for this study and the results from the interviews. The final section is devoted to a discussion of the results of this study and its implications for future research, managerial practice, and public policy.

\section{Theoretical Background}

\subsection{Entrepreneurial Intention}

Since the decision to become an entrepreneur may be plausibly considered as voluntary and conscious (Krueger et al., 2000), it seems reasonable to analyze how that decision is taken. The entrepreneurial intention has been considered as the key element to understand the new-firm creation process. Entrepreneurial intention can be defined as the intention of an individual to set up a new business venture some time in the future (Thompson, 2009).

Several models aiming to explain entrepreneurial intention have been developed, such as the Entrepreneurial Event Model of Shapero (1982) or Maximization of the Expected Utility (Douglas and Shepherd 2000).

Consequently the Theory of Planned Behavior (Ajzen, 1991) has become the most frequently used theoretical framework in recent studies of entrepreneurial intention (Alexei and Kolvereid 1999; Audet 2002; Autio et al. 2001; Krueger, Reilly and Carsrud 2000; van Gelderen et al. 2006). This framework consists of three elements. The first component of the TPB is the attitude toward the behavior that is a person's overall evaluation of the behavior. The second component of the model is the subjective norm, which is defined as a person's own estimate of the social pressure to perform, or not perform, the entrepreneurial behavior. The third component is the Perceived Behavioral Control that relates to perceptions of the behavior's feasibility, which is an essential predictor of the behavior (Ajzen, 1991).

From the last institutional approach, some entrepreneurial models with a cognitive basis emerged to explain this phenomenon: the Entrepreneurial Event Theory (Shapero and Sokol, 1982) and the Theory of Planned Behavior (Ajze, 1991) appeared as the main theory-driver models. Accordingly, entrepreneurial intention has to be understood in the context of entrepreneurial environments.

\subsection{Institutional Framework}

The study of institutions is one of the most enduring interests in the social sciences. All the major disciplines - anthropology, economics, political science, psychology, and sociology — have become engaged and each has given its particular thrust and contour to the current (Scott 1994:55).

Institutional environment influences the perceptions of desirability and feasibility, society's social and cultural environment, such as beliefs, values and attitudes, conditions behavior and decisions made by individuals (Díaz-Casero et al., 2009). 
North (1990) proposed that the institutional framework of a society, which he defined as comprising "the fundamental political, social and legal ground rules, which establish the basis for production and distribution" limits the scope of strategic choices available to individuals and organizations.

Scott (1995) offered a more refined categorization of these formal and informal institutions that impact businesses into regulatory, normative, and cognitive categories. Regulatory institutions are formally codified, enacted and enforced system of laws in a community, society or nation. Cognitive institutions refer to the culture-specific beliefs about socially appropriate behavior, which are acquired through the process of socialization by living or growing up in a community or society (Hirsch and Lounsbury, 1997). The last pillar of institutional environment categorized by Scott (1995) is normative dimension, which refers to "the degree to which a country's residents admire entrepreneurial activity and value creative and innovative thinking" .It is also manifested in the standards and norms of the society (Manolova et al., 2008). According to Scott (1995), this type of institutional dimension is embedded in three types of 'carriers' which include cultures, social structures, and routines that surround and form work activities such as occupational choices.

\subsection{Entrepreneurial Intention and Institutional Factors}

The rate of new venture formation and growth is directly influenced by the institutional environment (Hwang and Powell, 2005; Gnyawali and Fogel, 1994; Aldrich, 1990). In other words, the institutional environment of a society plays a powerful role in creating and even destroying entrepreneurship in a country (Aldrich and Wiedenmayer, 1993). The work of both William Baumol (1990, 1993, and 2005) and Douglass North (1990, 1994, 1997, and 2005) has highlighted the relationship between the institutional environment and entrepreneurship development. Baumol (2005) in particular suggests that productive entrepreneurship will be at low levels where the incentives supporting it are weak. According to North, entrepreneurs are the main agents of change. Even if previous research provides important information on the role of institutions in promoting entrepreneurship on the country level (Acs, et al., 2008, Aidis, et al., 2008, Bowen \& DeClercq, 2008, Hessels, et al., 2008), entrepreneurs' perceptions of institutions are still poorly understood. Institutions affect the levels and types of entrepreneurship in a country or region through the behavior of entrepreneurs, which, again is influenced by how these entrepreneurs perceive their environment and institutions. Researching the relationship between institutions and intentions is important for entrepreneurship, as the institutional environment defines, creates, and limits entrepreneurial aspirations, intentions, and opportunities, and thus affects the speed and scope of entrepreneurial entry rates (Shane, 2004).

\subsection{Normative Institutional Factors for Entrepreneurs}

Individuals are influenced in their economic choices by both injunctive norms (which involve the perception of the right thing to do) and descriptive norms (which involve the description of others' behavior) (Cialdini, 2007). The importance of incorporating normative influences in organizational research has led to a number of approaches for measuring such norms. Krueger (2000), e.g., builds on Ajzen's $(1987,1991)$ model of behavior intent, incorporating an individual's perceived social norms as one factor influencing intent to start a new venture. Several researchers have argued that the extent to which a society respects and admires entrepreneurs is a better predictor of domestic entrepreneurship than are more general cultural measures (Spencer \& Gómez, 2004). Social norms are present at a group level, suggesting that a collective believes a certain value is very important (Lipset, 2000)

Normative institutions relate to the level of admiration of entrepreneurs and entrepreneurial activity held by members of a society (Bruton et al., 2005).

Normative systems are typically composed of values (what is preferred or considered proper) and norms (how things are to be done, consistent with those values) that further establish consciously followed ground rules to which people conform (Scott, 2007). Normative institutions therefore exert influence because of a social obligation to comply, rooted in social necessity or what an organization or individual should be doing (March \& Olsen, 1989). Some societies have norms that facilitate and promote entrepreneurship and its financing while some other societies discourage it by making it difficult (though not illegal), often unknowingly (Baumol et al., 2009; Soto, 2000).

Davidsson and Wiklund (1997), offer two views in terms of the normative environment effecting entrepreneurship: Firstly, the supportive environment perspective or societal legitimization perspective where prevailing values and beliefs, among others, may make a person more or less inclined towards new venture formation. Secondly, because some regions have a larger pool of entrepreneurs, entrepreneurship leads to more entrepreneurship and the degree of entrepreneurial activities is an outcome of a dynamic process in which social habits (entrepreneurial memory) are as important as legal and economic factors. 


\section{Research Methodology}

This research has been developed based on the qualitative method. Qualitative research is a method of inquiry employed in many different academic disciplines, traditionally in the social sciences, but also in market research and further contexts. Qualitative researchers aim to gather an in-depth understanding of human behavior and the reasons that govern such behavior (Denzin and Lincoln, 2005).

In total 12 semi-structured interviews with Information Technology entrepreneurs were conducted between summer and autumn 2011. Interviews are particularly useful for getting the story behind a participant's experiences. The interviewer can pursue in-depth information around the topic. Interviews may be useful as follow-up to certain respondents to questionnaires, e.g., to further investigate their responses .The method of interview, involved a face-to-face meeting in which a researcher (interviewer) asks an individual a series of semi-structure questions. Each interview takes in average 60 minutes. All Interviews were recorded and then transcribed for content analysis and conclusions.

The age of the business of all entrepreneurs was smaller than 5 years. All of the entrepreneurs had educational degree. The average age of them was 35. Between entrepreneurs who participated in interview 6 ones were active in service sector. 4 entrepreneurs worked in software production and 2 of them had hardware production firm.

In alignment to analyzing the data collected in the interview phase, open and the axial coding technique has been applied. Open coding fractures the data and allows the researcher to identify some categories, their properties and dimensions. Axial coding puts these data back together in new ways by making connections between categories (Silverman, 1993).

\section{Findings}

Coding is the process of combing the data for themes, ideas and categories and then marking similar passages of text with a code label so that they can easily be retrieved at a later stage for further comparison and analysis. Coding can be carried out by selecting segments of text using line numbering in the document, or by highlighting the specific quotation to be coded.

The initial stage in data acquisition is open coding. Variables involved in the phenomenon are identified, labeled, categorized and related together in an outline form. At the first step, the content of interview meetings imported in the tables and the core concepts extracted.

To conduct a content analysis on any such text, the text is coded or broken down into manageable categories on a variety of levels - word, word sense, phrase, sentence, or theme - and then examined using one of content analysis basic methods, either conceptual analysis, or relational analysis. All levels of content analysis have been presented in this section. First, the analysis of one interview as a sample is given in table 1. In this interview, three normative factors affecting intention of entrepreneurs have been identified.

$<$ Table 1 about here $>$

In the first step, all factors identified from each interview are coded and have been presented in table 2.

$<$ Table 2 about here $>$

There are many repetitive factors in 12 interviews. In the second step, all repetitions were omitted. In the last step, the factors presented in table 3 have been categorized in four groups based on their nature. Axial coding is the next stage after open coding. In axial coding, data are put together in new ways. This is achieved by utilizing a 'coding paradigm', i.e. a system of coding that seeks to identify causal relationships between categories. The aim of the coding paradigm is to make explicit connections between categories and sub-categories. Table 3 shows the concepts classified in four categories in this research.

$<$ Table 3 about here $>$

After content analysis on 12 interviews, the normative factors affecting intention of entrepreneurs have been identified in four groups of factors family context, believes, norms and expectations, social networks and country technology conditions. The final research model was presented in figure 1.

$<$ Figure 1 about here $>$

\section{Conclusion}

Environment is an important element in entrepreneurship and entrepreneurial intention is affected by environmental events. In fact environment could be a facilitator or impediment to entrepreneurial intention in a society. Institutional environment affects the perceptions of desirability and feasibility, society's social and cultural environment, such as beliefs, values and attitudes, conditions behavior and decisions made by individuals. Normative institutions therefore 
exert influence because of a social obligation to comply, rooted in social necessity or what an organization or individual should be doing.

This study was carried out to achieve this objective: Identifying the normative factors affecting entrepreneurial intention in Information technology sector in Iran. In this research paper, thirteen normative institutional factors were identified and categorized in three dimensions. The results indicate that in Iran, entrepreneurs in IT sector believe that family context, social network, technology conditions, society's norms and expectation play an important role in creating intention to start a firm. Entrepreneurs emphasized that parent's job and educational level as the family contexts exert influence on intention. The findings show that two normative factors that affect women's entrepreneurial intention are society's attitudes to women's skills and behaviors and their roles in family. Only females imply that family support play a role in creating intention to start a business. Technology growth and the entry of new technology to country do have important impact on entrepreneurial intentions in both men and women group in IT sector.

Figure 1 resulted from our qualitative study show all normative factors affecting entrepreneurial intention of entrepreneurs in IT sector in Iran.

This study is the first to identify those elements in detail. Previous researches focused on different factors affecting entrepreneurial intention, so they didn't go through details.

The results of this study support the previous research. Previous studies have revealed the importance and influences of a country's institutional profile on entrepreneurship (e.g., Ahlstrom and Bruton, 2006; Manolova et al., 2008).

In this study social norms and believes identified as one of the normative factors that affects entrepreneurial intention. Other studies mention that this factor affects the perceptions of desirability and feasibly, conditions behavior and decisions made by individuals (Díaz-Casero et al., 2009).

Although, in no research have the role of family context in fostering entrepreneurial intention been identified in such details, there are some evidence about the parents role as a model for entrepreneurs (Rajiman, 2001; fairly, 2004).

The effect of the technology conditions on entrepreneurial intention has not been considered in any research.

One other normative institutional factor identified in this study as a factor affecting entrepreneurial intention is social network. In the last decade, sociologists and organization theorists have also provided significant contributions to the theory of entrepreneurial behavior. In particular, they have shown that social networks are crucial factors in the decision whether to become entrepreneurs (Gulati, 1999, 1998). Aldrich and Zimmer (1986) have shown that participation in social networks is a crucial element for entrepreneurs. However there is no research about the role and the effects of social networks on entrepreneurial intention.

Implications of our results may be derived in at least two areas. First, regarding institutional approach, more attention should be paid to the effect of different normative factors on entrepreneurial intention. Our results indicate that social norms do have an impact on intention to start a firm. Specifically, our findings provide initial evidence to support this theory that areas with higher norms of environmentally responsible consumption have higher levels of entrepreneurial founding in support of environmental practice. Second, implications for public decision makers could also be derived. It should be considered by Iranian government to focus on normative factors of country in order to present the appropriate policy support for entrepreneurs.

There are some limitations in the current study where the data is primary data collected from entrepreneurs in IT sector. This research can also be done in other sector and industry in Iran. Future research may also extend the model to include other factors such as regulatory and cognitive factors and increase the sample size to increase the validity of the study

The future research can be also extended to identify the influences and impacts among the variables and the entrepreneurial intentions among entrepreneurs.

It is hoped that this study provides some implications for policy makers in Iran to further develop means to enhance entrepreneurship in different groups of people so that the country can enjoy economic expansion. Therefore, developing environmental criteria for entrepreneurs will expand systemic means to thrive entrepreneurship in a region.

\section{References}

Ahlstrom, D. \& Bruton, G. D. (2006). Venture Capital in Emerging Economies: Networks and Institutional Change, Entrepreneurship Theory and Practice, 30 (2), 299-320, http://dx.doi.org/ 10.1111/j.1540-6520.2006.00122.x

Azjen, I. (1991). Theory of planned behavior, Organizational Behavior and Human Decision Processes, 50, 179-211, http://dx.doi.org/ 10.1016/0749-5978(91)90020-T 
Aldrich, H., Zimmer, C. (1986). Entrepreneurship through social networks. In: Sexton, D., Smilor, R. (Eds.), The Art and Science of Entrepreneurship. Ballinger, Cambridge.

Baumol, W. J., Litan, R. E., \& Schramm, C. J. (2009). Good capitalism, bad capitalism, and the economics of growth and prosperity. New Haven, CT: Yale University Press.

Bosma, N., Acs, Z. J., Autio, E., Coduras, A., \& Levie, J. (2009). Global entrepreneurship monitor: 2008 executive report. Babson Park, MA: Global Entrepreneurship Research Consortium.

Bruton, Garry D., Ahlstrom, D. \& Li, H. (2010). Institutional Theory and Entrepreneurship: Where Are We Now and Where Do We Need to Move in the Future? 1042-2587C 2010 Baylor University, http://dx.doi.org $/ 10.1111 / \mathrm{j} .1540-6520.2010 .00390 . x$

Bruton, G. D. \& Ahlstrom, D. (2003). An institutional view of China's venture capital industry: Explaining the differences between China and the West. Journal of Business Venturing. 18(2), 233-260. , http://dx.doi.org/ 10.1016/S0883-9026(02)00079-4

Cialdini, R. (2007). Descriptive social norms as underappreciated sources of social control. Psychometrical 72 (2), 263-268, http://dx.doi.org/ 10.1007/s11336-006-1560-6

Davidsson, P. \& Wiklund, J. (1997). Values, beliefs, and regional variation in new firm formation rates. Journal of Economic Psychology, 18 (2-3), 179-199, http://dx.doi.org/10.1016/S0167-4870(97)00004-4

Denzin, N. K. \& Lincoln, Y. S. (Eds.). (2005). The Sage Handbook of Qualitative Research (3rd ed.). Thousand Oaks, CA: Sage.

Elster, J. (1989). Social norms and economic theory. Journal of Economic Perspectives. 3 (4), 99-117. , http://dx.doi.org/ 10.2307/i333433

Fairlie, R. (2008). Kaufman Index of Entrepreneurial Activity: 1996-2007. Ewing Marion Kaufman Foundation, Kansas City, MS.

Gulati, R. (1999). Network location and learning: the influence of network resources and firm capabilities on alliance formation. Strategic Management Journal. 99, 397-420, http://dx.doi.org/ 10.1002/(SICI)1097-0266

Gulati, R. (1998). Alliances and networks. Strategic Management Journal. 98, 293-317, http://dx.doi.org $/ 10.1108 / 09600030510599931$

Hwang, H., \& Powell, W.W. (2005). Institutions and Entrepreneurship. In Acs, Z.J., and Audretsch, D.B. (Eds.). Handbook of entrepreneurship research. Kluwer: 179-210.

Ingram, P. L. \& Silverman, B. S. (2002). The New Institutionalism in Strategic Management. JAI, Amsterdam; Boston.

Korunka, C., Frank, H., Lueger, M. \& Mugler, J. (2003). The entrepreneurial personality in the context of resources, environment, and the startup process - A configurational approach. EntrepreneurshipTheory and Practice. 28(1), 23-42, http://dx.doi.org/10.1111/1540-8520.00030

Krueger, N. F, Reilly, M. D. \& Carsrud, A. L. (2000). Competing Models of Entrepreneurial Intentions. Journal of Business Venturing. 15, 411-432, http://dx.doi.org/10.1016/S0883-9026(98)00033-0

Krueger, N. F. (2007). What lies beneath? The experiential essence of entrepreneurial thinking. Entrepreneurship Theory and Practice. 31(1), 123-138, http://dx.doi.org/10.1111/j.1540-6520.2007.00166.x

Lipset, S. M. (2000). Values and entrepreneurship in the Americas. Swedberg, R. (Ed.), Entrepreneurship: the Social Science View.

Manolova, Tatiana S., Eunni, Rangamohan V. \& Gyoshev, B. S. (2008). Institutional Environments for Entrepreneurship: Evidence from Emerging Economies in Eastern Europe. Entrepreneurship Theory and Practice. 32(1), 203-218, http://dx.doi.org/10.1111/j.1540-6520.2007.00222.x

Moskovitch, I. \& Kim, D. (2008). Building an Entrepreneurial Economy: The Case of Korea 1998-2005, Global Economic Review. 37 (1), 63-73. http://dx.doi.org/10.1080

North, D. C. (1990). Institutions, institutional change and economic performance. Cambridge: Cambridge University Press.

North, D. C. (1993). Prize lecture. Lecture to the memory of Alfred Nobel, Stockholm. December 9.

North, D. C. (2005). Understanding the process of economic change. Princeton: University Press.

Reynolds, P. D., Camp, S. M., Bygrave, W., Autio, E., \& Hay, M. (2001). Global entrepreneurship monitor, 2001 executive report. Kansas City, MO: E.M. Kauffman Foundation.

Shapero, A. \& L. Sokol. (1982). The social dimensions of entrepreneurship. Encyclopedia of Entrepreneurship. C. A. Kent, D. L. Sexton and K. H. Vesper. Englewood Cliffs, N J, Prentice Hall: 72-90.

Shapero, A. (1985). "The entrepreneurial event. Enterprise February: 5-9.

Shane, S., \& Venkataraman, S. (2000). The promise of entrepreneurship as a field of research. Academy of Management Review. 25, 217-226, http://dx.doi.org/10.5465/AMR.2000.2791611 
Shane, S. (2004). A General Theory of Entrepreneurship: the Individual-Opportunity Nexus. Edward Elgar Publishing Incorporated, Northampton.

Silverman, D. (1993). Interpreting Qualitative Data, Methods for Analysing Talk, Text and Interaction, London: Sage Publications.

Soto, H.D. (2000). The mystery of capital: Why capitalism triumphs in the West and fails everywhere else. New York: Basic Books.

Spencer, J. W. \& Gomez, C. (2004). The Relationship among National Institutional Structure, Economic Factors, and Domestic Entrepreneurial Activity: A Multicountry Study. Journal of Business Research. 57 (10), 1098-1107, http://dx.doi.org/10.1016/S0148-2963(03)00040-7

Scott, W. R. (1994). Institutions and organizations. Towards a theoretical synthesis. In W. R. Scott, \& J. W. Meyer (Eds.) Institutional environments and organizations. California: Sage.

Scott, W. R. (2007). Institutions and organizations: Ideas and interests. Thousand Oaks, CA: Sage Publications.

Table1. Verbal statement and derived components from a sample interview

\begin{tabular}{|c|l|l|}
\hline Interview & \multicolumn{1}{|c|}{ Verbal Statement } & \multicolumn{1}{c|}{ Components } \\
\hline \multirow{3}{*}{1} & $\begin{array}{l}\text { In my opinion the family has an important role in } \\
\text { children view about the entrepreneurship. }\end{array}$ & 1. Family style \\
\cline { 2 - 4 } & $\begin{array}{l}\text { Family's feeling support can reduce the stress of } \\
\text { someone who is going to start a firm. }\end{array}$ & $\begin{array}{l}\text { 2. Family feeling } \\
\text { Support. }\end{array}$ \\
\cline { 2 - 4 } & $\begin{array}{l}\text { In our society, people have special view about } \\
\text { women skills. }\end{array}$ & $\begin{array}{l}\text { 3. Social views about } \\
\text { women skills }\end{array}$ \\
\hline
\end{tabular}


Table2. Extracted concepts from each interview

\begin{tabular}{|c|c|}
\hline Interview No. & Concepts \\
\hline 1 & $\begin{array}{l}\text { 1. The family style } \\
\text { 2. Social views about women skills } \\
\text { 3. Family feeling support }\end{array}$ \\
\hline 2 & $\begin{array}{l}\text { 4. The Technology growth in the society } \\
\text { 5. The family style }\end{array}$ \\
\hline 3 & 6. $\quad$ Parent educational level \\
\hline 4 & $\begin{array}{l}\text { 7. Parents experience } \\
\text { 8. Society's negative believe of women ability }\end{array}$ \\
\hline 5 & $\begin{array}{l}\text { 9. People attitude to internal goods } \\
\text { 10. Social network and the effective communication } \\
\text { 11. Women role model }\end{array}$ \\
\hline 6 & $\begin{array}{l}\text { 12. Parents role in creating entrepreneurship culture in family } \\
\text { 13. Encouraging people to be entrepreneur by honoring entrepreneurs } \\
\text { 14. Society's attitude to entrepreneurs }\end{array}$ \\
\hline 7 & $\begin{array}{l}\text { 15. Family expectation from women } \\
\text { 16. Female tasks as a household }\end{array}$ \\
\hline 8 & $\begin{array}{l}\text { 17. The entry of new technology to country } \\
\text { 18. Parents educational level }\end{array}$ \\
\hline 9 & $\begin{array}{ll}\text { 19. } & \text { Family life style } \\
\text { 20. } & \text { Easy access to new technology } \\
\text { 21. } & \text { The spouse support } \\
\end{array}$ \\
\hline 10 & $\begin{array}{l}\text { 22. The entry of new technology } \\
\text { 23. Parents job }\end{array}$ \\
\hline 11 & $\begin{array}{l}\text { 24. Family support } \\
\text { 25. Societies negative believe of entrepreneurs } \\
\text { 26. Role model } \\
\text { 27. Access to technology }\end{array}$ \\
\hline 12 & $\begin{array}{ll}\text { 28. } & \text { Family training style } \\
\text { 29. } & \text { Family background } \\
\text { 30. } & \text { Parents educational level } \\
\end{array}$ \\
\hline
\end{tabular}

Table3. Extracted dimensions

\begin{tabular}{|l|l|}
\hline \multicolumn{1}{|c|}{ Dimension } & \multicolumn{1}{c|}{ Components } \\
\hline Family Context & $\begin{array}{l}\text { Parents' education level } \\
\text { Parents' job and experience } \\
\text { Family Life style } \\
\text { Family's feeling supports }\end{array}$ \\
\hline Believes, norms and expectations & $\begin{array}{l}\text { People believe about applying internal goods } \\
\text { Society's view on entrepreneur } \\
\text { Society's attitudes to women skills and behaviors } \\
\text { Women responsibility at home }\end{array}$ \\
\hline Social networks & $\begin{array}{l}\text { Social network and effective communication } \\
\text { Role Model }\end{array}$ \\
\hline \multirow{2}{*}{ Country technology conditions } & $\begin{array}{l}\text { New technology entry } \\
\text { General access to technology } \\
\text { The technology maturity in society }\end{array}$ \\
\hline
\end{tabular}




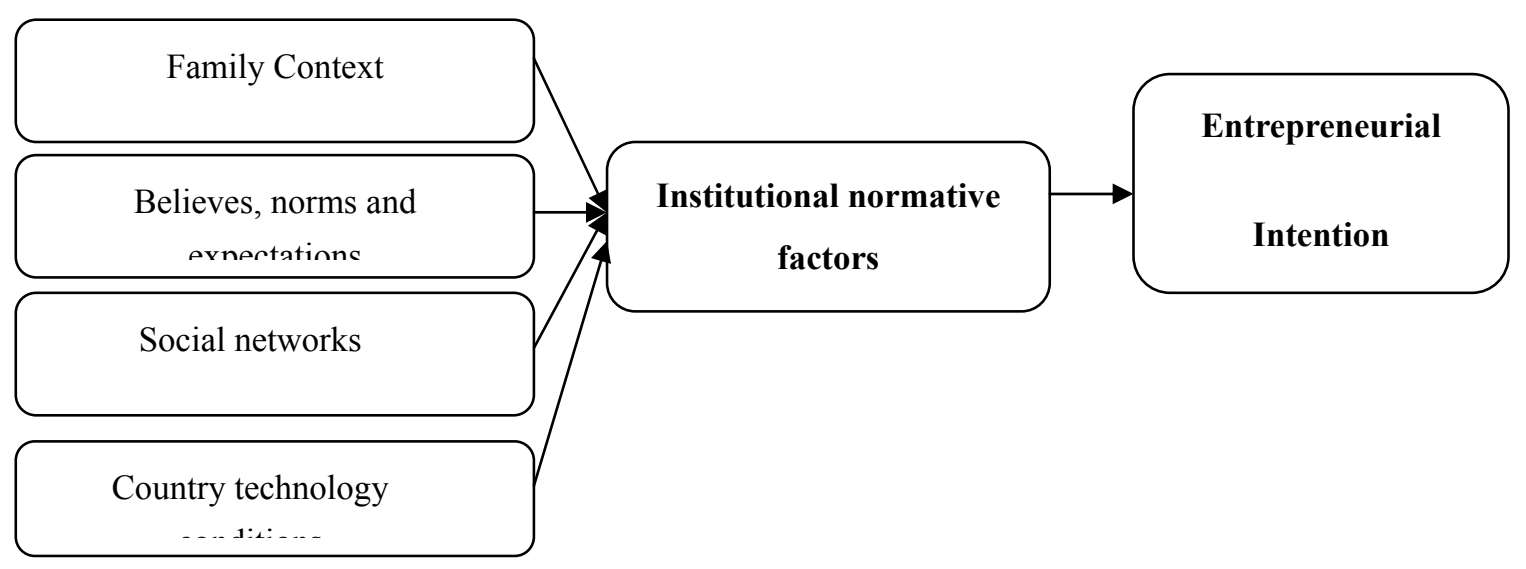

Figure1. Normative Institutional Factors affecting Entrepreneurial Intention 